\title{
国際実装技術フォーラム '99印象記
}

\section{International Packaging Forum '99}

$$
\text { レポーター：宇都宮 久修 (インターコネクション・テクノロジーズ/中小企業診断士） }
$$

国際実装技術フォーラムは，「2010年をターゲットにし た実装技術のロードマップ」をテーマに，9月 7 日の 9 時 から 5 時半まで東京国際フォーラムで開催された。

川西剛会長のご挨拶に続き，講師はエレクトロニクス実 装学会が本年 6 月に出版した「2010年のエレクトロニクス 実装技術ロードマップ」を担当した実装技術ロードマップ 委員会のメンバーとして, 以下の13名（宮代文夫：東芝ケ ミカル, 友井正男: 横浜国立大学, 藤本淳：日本電気, 高 橋邦明：東芝, 上芳夫：電気通信大学, 雀部俊樹 : シプレ イファーイースト, 城戸靖彦 : 城戸事務所, 津久井勤：東 海大学, 原靖彦: 日本大学, 中野義昭 : 東京大学, 内海和 明：日本電気, 塚田裕：日本アイ・ビー・エム, 本多進： 昭栄ラボラトリー）と，今年 8 月に「1999年度版日本実装 技術ロードマップ」を出版した日本電子機械工業会を代表 して春日壽夫（日本電気），「電子SIの現状」に関連して大 崎孝明（NTTアドバンステクノロジ），「実装技術コンソ ーシアムの現状」に関連して大塚寛治 (明星大学), 今年 11月末に全世界に向けて公開される国際半導体技術ロード マップ ( International Technology Roadmap for Semiconductors)に関連してDr. Chi Shih Chang(SEMAT$\mathrm{ECH})$ の合計18名が, 限られた時間内に精力的な活動報告 と, 2010年の実装技術の「あるべき姿」について, 示唆に 満ちた講演を行った。

実装技術に関連するロードマップは, 前述の通り日本電 子機械工業会 (EIAJ), エレクトロニクス実装学会 (JIEP), 米国半導体工業会 (SIA：Semiconductor Industry Association), 米国プリント配線板工業会 (IPC), 米国電 子機器製造工業会 ( NEMI：National Electronics Manufacturing Initiative) および国際半導体技術ロード マップ委員会 (ITRS : International Technology Roadmap for Semiconductors）が各々独立して, あるいは協力 して, エレクトロニクス実装学会を除き， 2 年おきに出版 している。

ロードマップの作成目的は，10年後の将来技術の予測を 行うことで, 産・学・官の連携を活用して, より資源を集 中し, 効率的・効果的な技術開発を行い, その結果として 競争優位性を維持・向上させることにある。技術革新の進 展が著しいエレクトロニクス業界において, 将来予測を行
い, その指針に基づいた産・学・官の戦略的連携による研 究開発活動・事業活動を行うことが重要であることは言及 に及ばない。

さて, 今回の国際実装技術フォーラムでは, JIEP実装 技術ロードマップ委員会の努力の結果が, 各委員会20分の 持ち時間で発表された。発表内容詳細は, すでに当日配付 のレジュメおよび 6 月出版の「2010年のエレクトロニクス 実装技術ロードマップ」に記載されているため,ここでは 割愛する。20分という短時間に各委員会の活動結果をまと める作業がいかに大変であったかは, 容易に想像がつくが, 盛り沢山の内容を 1 日のフォーラムに凝縮してしまったた め, 発表者に発表内容の制限が加えられてしまったことと, また受講者には質問の時間が与えられなかったことが，き わめて残念であった。また最後の講演が英語で行われたた め, 多くの日本人受講者は翻訳を聴くためのへッドセット を持っておらず，その内容が理解できないという不都合も 生じた (ヘッドセットを持っていた受講者も講演者の発言 速度が速く, 通訳が追い付けないため, 発表の真意が伝わ りにくいという問題もあった)。しかしながら，JIEPが編 纂したロードマップの啓蒙普及の第 1 弾として,「広くそ の存在を知らしめる」という見地からは成功したと言えよ 门。

今後の実装技術の「あるべき姿」を論じるためにも，わ が国のエレクトロニクス業界の発展のためにも, 今回編纂 したロードマップの成果を, より多くの人々に報告し，ま たより多くの人々の意見を頂戴して, ロードマップの内容 をより成熟化させていく努力や機会が必要と感じられたの は，筆者だけではないと思われる。少なくても各章 1 時間 程度の講演と質疑応答時間を設けたセミナーの国内外にお ける開催や, 今後 2 年に 1 回あるいは 3 年に 1 回の頻度で のロードマップの継続編纂事業を続けていただくことを願 うものである。

最後に，ロードマップ編纂に従事された各委員のご努力 と, それを支えた事務局をはじめとする会員各社・各機関 の人々のご努力に敬意を払うとともに，その成果を現実の ものとするためのさらなる啓蒙普及活動の企画化・実現化 の早期実施を切に願うものである。 